\title{
ANALISIS PENGUKURAN KINERJA DENGAN MENGGUNAKAN KONSEP VALUE FOR MONEY PADA PEMERINTAH KOTA LHOKSEUMAWE (STUDI KASUS PADA DPKAD KOTA LHOKSEUMAWE PERIODE 2014-2016)
}

\author{
Indrayani $^{1}$, Khairunnisa ${ }^{2}$ \\ ${ }^{1,2}$ Prodi Akuntansi Fakultas Ekonomi dan Bisnis Universitas Malikussaleh Lhokseumawe \\ Indrayani@unimal.ac.id
}

\begin{abstract}
This study aimed to determine the performance of the Office of Revenue Finance and Regional Assets (DPKAD) Lhokseumawe City by using the concept of Value For Money. This research was conducted by taking data for 3 years, from 2014 to 2016. This research used secondary data. The method of data analysis used is descriptive qualitative analysis method. Based on the research result by using Value For Money concept based on 3 main elements such as economic, efficiency and effectiveness show that: Economic ratio, get 86,54\%, 82,64\% and 71,43\% which means the economic ratio was under 100\% during 2014-2016 and the result of this ratio indicated that the economic ratio criterion obtained the "economical" category.the efficiency ratios during the research year of this ratio were 94,69\%, 105,17\% and 97,95\%, although in 2015 the ratio was less efficient because it was in percentage above 100\%. However, the overall performance of the Lhokseumawe City Government has been categorized as "efficient". While the effectiveness ratio, obtained $96,53 \%, 86,65 \%$ and $76,98 \%$, where the percentage ratio below $100 \%$ indicates that this ratio obtains "ineffective" criterion. Based on the result, the concept of Value For Money is very good to be applied on DPKAD of Lhokseumawe city because it can provide a more structured and comprehensive performance overview.
\end{abstract}

Keywords: Performance, Value For Money, Economics, Efficiency, Effectiveness. 


\section{PENDAHULUAN}

Perkembangan akuntansi sektor publik di Indonesia mengalami kemajuan yang pesat seiring dilaksanakannya otonomi daerah. Otonomi daerah adalah hak, wewenang, dan kewajiban daerah otonom untuk mengatur dan mengurus sendiri urusan pemerintahan serta kepentingan masyarakat setempat sesuai dengan perundang-undangan (Anonim dalam Sari, 2014). Hak otonomi kepada masing-masing daerah atau kabupaten akan memberikan kebebasan untuk mengolah dan meningkatkan sumber pendapatannya, demi kesejahteraan masyarakat dan kemajuan daerah tersebut. Semakin tinggi realisasi pendapatan yang dicapai, hendaknya dapat mencerminkan semakin baik kinerja pemerintah daerah sesuai dengan hasil yang telah dicapai. Oleh sebab itu, masyarakat dituntut untuk lebih berfikir kritis terhadap kinerja pemerintah daerah, dibutuhkannya transparansi dan akuntabilitas publik oleh lembaga sektor publik. Akuntabilitas bukan hanya sekedar kemampuan lembaga sektor publik menunjukkan bagaimana uang publik tersebut digunakan, tetapi juga meliputi kemampuan memberikan jaminan dari penggunaan sumber-sumber dana publik termasuk pengalokasian sumber daya secara ekonomis, efisien dan efektif melalui pelaksanaan manajemen publik yang baik (Sari, 2014).

Pemberian otonomi dan desentralisasi yang luas, nyata, dan bertanggungjawab kepada Kabupaten/Kota akan membawa konsekuensi perubahan pada pola dan sistem pengawasan yang mendasar dengan diberinya keleluasaan kepada pemerintah daerah untuk mengatur dan mengurus daerahnya sendiri (Nugrahani, 2007). Keberhasilan otonomi daerah tidak lepas dari kinerja pemerintah daerah dalam mengelola keuangan daerahnya.

Pengukuran kinerja merupakan faktor penting di dalam suatu organisasi, termasuk juga untuk organisasi sektor publik. Pengukuran kinerja sangat diperlukan untuk menilai akuntabilitas organisasi dalam menghasilkan pelayanan publik yang lebih baik dan tepat sasaran. Pengukuran kinerja sektor publik dilakukan untuk memenuhi tiga maksud. Pertama, pengukuran kinerja sektor publik dimaksudkan untuk membantu memperbaiki kinerja pemerintah. Kedua, ukuran kinerja sektor publik digunakan untuk pengalokasian sumber daya dan pembuatan keputusan. Ketiga, ukuran kinerja sektor publik dimaksudkan untuk mewujudkan pertanggungjawaban publik dan memperbaiki komunikasi kelembagaan (Ulum,2012:21). Ukuran kinerja pemerintah daerah berdasarkan anggaran berbasis kinerja dapat diukur menggunakan konsep value for money, yakni ekonomis, efisiensi, dan efektivitas (Khikmah, 2014).

Menurut Mardiasmo (2004:4) Value for money merupakan konsep pengelolaan organisasi sektor publik yang mendasarkan pada tiga elemen utama, yaitu ekonomi, efisiensi dan efektifitas. Elemen yang pertama dari konsep value for money yaitu ekonomi. Ekonomi adalah pemerolehan input dengan kualitas dan kuantitas tertentu pada harga yang terendah. Ekonomi terkait dengan sejauh mana organisasi sektor publik dapat meminimalisir input resources yang digunakan yaitu dengan menghindari pengeluaran yang boros dan tidak produktif. Elemen yang kedua dari konsep value for money ialah efisiensi. Efisiensi yaitu pencapaian output dengan input tertentu atau penggunaan input yang terendah untuk mencapai output tertentu. Semakin rendah nilai rasio efisiensi yang di peroleh, maka semakin bagus pula kinerja organisasi sektor publik tersebut. Dan elemen yang terakhir dari konsep value for money yaitu efektifitas. Efektivitas adalah tingkat pencapaian hasil program dengan target yang ditetapkan. Secara sederhana, efektifitas merupakan perbandingan outcome dengan output. Kota Lhokseumawe sudah diresmikan menjadi sebuah kota otonom, akibat dari pemisahan dirinya dari kabupaten aceh utara sejak tahun 2001. Pemisahan ini mengharuskan Kota Lhokseumawe untuk mengatur dan mengurus sendiri urusan pemerintahan serta mendapatkan kebebasan untuk mengolah dan meningkatkan sumber pendapatan daerahnya, demi kesejahteraan masyarakat dan kemajuan daerahnya.

Dinas Pengelolaan Keuangan dan Aset Daerah (DPKAD) Kota Lhokseumawe merupakan dinas daerah yang memegang peranan dan fungsi strategis di bidang pengelolaan keuangan dan aset daerah Kota Lhokseumawe. Pengelolaan Anggaran Pendapatan dan Belanja Daerah (APBD) Kota Lhokseumawe memiliki pola yang jelas dan jumlah anggaran yang semakin besar. Tahun anggaran 2014, prioritas APBD adalah meningkatkan pelayanan publik. Sedangkan tahun 2015 dan 2016, diarahkan pada peningkatan pembangunan infrastruktur untuk memacu ekonomi dan kesejahteraan masyarakat. Jumlah anggarannya telah melebihi satu triliun rupiah dan kenaikannya cukup signifikan.

Tabel 1

Persentase Kinerja Pemerintah Kota Lhokseumawe dengan menggunakan Konsep Value For Money

\begin{tabular}{|l|c|c|c|}
\hline $\begin{array}{c}\text { Value For } \\
\text { Money }\end{array}$ & $\mathbf{2 0 1 4}$ & $\mathbf{2 0 1 5}$ & $\mathbf{2 0 1 6}$ \\
\hline $\begin{array}{l}\text { Rasio } \\
\text { Ekonomi }\end{array}$ & $86,54 \%$ & $82,64 \%$ & $71,43 \%$ \\
\hline $\begin{array}{l}\text { Rasio } \\
\text { Efisiensi }\end{array}$ & $94,69 \%$ & $105,17 \%$ & $97,95 \%$ \\
\hline $\begin{array}{l}\text { Rasio } \\
\text { Efektifitas }\end{array}$ & $96,53 \%$ & $86,65 \%$ & $76,98 \%$ \\
\hline
\end{tabular}


Sumber: Data Sekunder diolah, 2018

Dapat dilihat pada tabel persentase kinerja Pemerintah Kota Lhokseumawe dengan menggunakan konsep value for money yang di peroleh dari Laporan Realisasi Anggaran Pendapatan dan Belanja Daerah (RAPBD) Kota Lhokseumawe. Dimana rasio ekonomi diperoleh dari perbandingan anggaran pengeluaran (belanja) dengan realisasi pengeluaran. Secara keseluruhan dapat dilihat bahwa rasio ekonomis selama 3 tahun berturut-turut mengalami penurunan yang berarti bahwa hal tersebut baik bagi Pemerintah Kota Lhokseumawe karena rasionya bernilai di bawah $100 \%$.

Apabila dilihat dari segi efisiensi Dimana rasio efisiensi kinerja Pemerintah Kota Lhokseumawe cukup baik. Dimana pada tahun 2014 nilai rasio efisiensi yang di peroleh dari perbandingan realisasi belanja dengan realisasi pendapatan senilai $94,69 \%$ dan pada tahun 2015 naik menjadi $105,17 \%$ dan turun menjadi $97,95 \%$ pada tahun 2016, meskipun pada tahun 2015 menunjukkan rasio yang kurang efisien. Namun secara keseluruhan kinerja Pemerintah Kota Lhokseumawe telah efisien.

Dan apabila dilihat dari segi efektifitas, yang memperlihatkan perbandingan antara realisasi pendapatan dengan anggaran pendapatan. Yang berarti bahwa selama 3 tahun tersebut kinerja Pemerintah Kota Lhokseumawe tidak efektif, dikarenakan realisasi anggaran pendapatan lebih kecil dibandingkan dengan anggaran pendapatannya. Hal ini terbukti dengan masih adanya kekurangan, seperti banyaknya proyek fisik dan bantuan untuk masyarakat tak dapat direalisasikan dengan Anggaran Pendapatan dan Belanja Kota (APBK) perubahan tahun 2016, bahkan terutang pada pihak ketiga (Sumber: Serambi Indonesia, 11 Desember 2016, akses: 9 Oktober 2017).

Berdasarkan latar belakang diatas, terdapat ketertarikan penulis untuk melakukan penelitian mengenai pengukuran kinerja di Dinas Pengelolaan Keuangan dan Aset Daerah (DPKAD) Kota Lhokseumawe menggunakan konsep value for money dengan harapan dapat mencapai kinerja yang lebih baik. Sesuai dengan uraian di atas, maka penulis berminat mengambil judul penelitian "Analisis Pengukuran Kinerja Dengan Menggunakan Konsep Value For Money Pada Pemerintah Kota Lhokseumawe (Studi Kasus Pada DPKAD Kota Lhokseumawe Periode 2014-2016)".

\section{TINJAUAN PUSTAKA}

\author{
Kinerja \\ Kinerja Menurut Kristanti (2016) adalah suatu \\ tingkat dalam pencapaian dari pelaksanaan
}

kegiatan/program untuk mewujudkan sasaran, tujuan, misi, dan visi organisasi atau perusahaan. Namun menurut PP No. 8 Tahun 2006, kinerja adalah keluaran atau hasil dari kegiatan atau program yang hendak atau telah dicapai sehubungan dengan penggunaan anggaran dengan kuantitas dan kualitas terukur. Dengan demikian kinerja mencerminkan hasil atau prestasi kerja yang dapat dicapai oleh seseorang, unit kerja, dan atau suatu organisasi pada periode tertentu sesuai dengan wewenang dan tanggung jawabnya dalam upaya mencapai tujuan secara legal serta sesuai moral dan etika.

\section{Indikator Kinerja}

Indikator kinerja menurut Bastian (2006: 267) adalah ukuran kuantitatif dan kualitatif yang menggambarkan tingkat pencapaian suatu sasaran atau tujuan yang telah ditetapkan, dengan memperhitungkan indikator masukan (input), keluaran (output), hasil (outcome), manfaat (benefit), dan dampak (impact). Maksud dari indikator masukan, keluaran, hasil manfaat dan dampak adalah:

1. Indikator masukan (input) adalah segala sesuatu yang dibutuhkan agar pelaksanaan kegiatan dapat berjalan untuk menghasilkan keluaran. Indikator ini dapat berupa dana, sumber daya manusia, informasi, kebijakan/peraturan perundang-undangan, dan sebagainya.

2. Indikator keluaran (output) adalah sesuatu yang diharapkan langsung dicapai dari suatu kegiatan yang dapat berupa fisik dan/atau non fisik.

3. Indikator hasil (outcome) adalah segala sesuatu yang mencerminkan berfungsinya keluaran kegiatan pada jangka menengah (efek langsung).

4. Indikator manfaat (benefit) adalah sesuatu yang terkait dengan tujuan akhir dari pelaksanaan kegiatan.

5. Indikator dampak (impact) adalah pengaruh yang ditimbulkan baik positif maupun negatif terhadap setiap tingkatan indikator berdasarkan asumsi yang telah ditetapkan.

\section{Definisi Sistem Pengukuran Kinerja Organisasi Sektor Publik}

Menurut Nordiawan dan Atuningtyas (2011:157) pengukuran kinerja merupakan suatu proses sistematis untuk menilai apakah program/kegiatan yang telah direncanakan telah dilaksanakan sesuai dengan rencana tersebut, dan yang lebih penting adalah apakah telah mencapai keberhasilan yang telah ditargetkan pada saat perencanaan.

Menurut Mardiasmo (2004:121) Sistem pengukuran kinerja sektor publik adalah sistem 
yang bertujuan untuk membantu manajer publik menilai pencapaian suatu strategi melalui alat ukur finansial dan non finansial.

\section{Value For Money}

Menurut Mahmudi (2005:89) mengemukakan bahwa value for money adalah pengukuran kinerja untuk mengukur ekonomi, efisiensi, dan efektivitas suatu kegiatan, program, dan organisasi.

1. Ekonomi

Konsep ekonomi sangat terkait dengan konsep biaya untuk memperoleh unit input. Ekonomi berarti sumber daya input hendaknya diperoleh dengan harga lebih rendah (spending less), yaitu harga yang mendekati harga pasar. Input adalah semua jenis sumber daya masukan yang digunakan dalam suatu proses tertentu untuk menghasilkan output. Input tersebut dapat berupa tenaga kerja (tenaga, keahlian, dan keterampilan), serta aset-aset seperti gedung, peralatan, dan sebagainya.

\section{Efisiensi}

Efisiensi adalah hubungan antara barang dan jasa (output) yang di hasilkan dengan sumber daya (input) yang digunakan untuk menghasilkan output tersebut. Suatu organisasi, program, atau kegiatan dikatakan efisien apabila mampu menghasilkan output tertentu dengan input serendah-rendahnya, atau dengan input tertentu mampu menghasilkan output sebesar-besarnya (spending well).

3. Efektifitas

Efektivitas terkait dengan hubungan antara hasil yang diharapkan dengan hasil yang sesungguhnya dicapai. Efektivitas merupakan hubungan antara output dengan tujuan. Semakin besar kontribusi output terhadap pencapaian tujuan, maka semakin efektif organisasi, program, atau kegiatan. Jika ekonomi berfokus pada input dan efisiensi berfokus pada output atau proses, maka efektivitas berfokus pada outcome (hasil).

\section{Manfaat Implementasi Value For Money}

Penerapan konsep value for money dalam pengukuran kinerja pada organisasi sektor publik tentunya memberikan manfaat bagi organisasi itu sendiri maupun masyarakat. Manfaat yang dikehendaki dalam pelaksanaan value for money pada organisasi sektor publik yaitu: ekonomis (hemat cermat), efisien (berdaya guna) dan efektif (berhasil guna) (Mardiasmo 2004:130).

Manfaat lain dari implementasi konsep value for money menurut Mardiasmo (2004:7) antara lain:

1. Meningkatkan efektivitas pelayanan publik, dalam arti pelayanan yang diberikan tepat sasaran.

2. Meningkatkan mutu pelayanan publik.

3. Menurunkan biaya pelayanan publik.

4. Alokasi belanja yang lebih berorientasi pada kepentingan publik.
5. Meningkatkan kesadaran akan uang publik (public costs awareness) sebagai akar pelaksanaan akuntabilitas publik.

\section{Langkah-langkah Pengukuran Value For Money}

Menurut Mardiasmo (2004: 133) langkahlangkah pengukuran value for money adalah sebagai berikut:

1) Pengukuran Ekonomi

Pengukuran ekonomi hanya mempertimbangkan masukan (input) yang dipergunakan.

2) Pengukuran Efisiensi

Efisiensi diukur dengan rasio antara output dengan input. Semakin besar output dibanding input, maka semakin tinggi tingkat efisiensi suatu organisasi.

3) Pengukuran Efektifitas

Efektifitas adalah ukuran berhasil atau tidaknya suatu organisasi mencapai tujuannya.

4) Pengukuran Outcome

Outcome adalah dampak suatu program atau kegiatan terhadap masyarakat.

\section{Penelitian terdahulu}

Andriani, Sri (2012) meneliti tentang "Pengukuran Kinerja Dengan Prinsip Value For Money Pemerintah Kota Batu". Hasil penelitian ini menunjukkan rasio ekonomi tahun 2005 sampai dengan tahun 2009 menunjukkan bahwa kinerja Pemerintah Daerah Kota Batu ekonomis dalam merealisasilan pengeluaran karena rasionya kurang dari $100 \%$. Rasio efisiensi tahun 2005 sampai dengan tahun 2009 menunjukkan bahwa kinerja Pemerintah Daerah Kota Batu secara umum cukup efisien karena realisasi biayanya lebih tinggi dibandingkan dengan realisasi pendapatannya. Rasio efektifitas tahun 2005 sampai dengan 2009 menunjukkan bahwa kinerja Pemerintah Daerah Kota Batu secara umum efektif karena hasil rasio nya lebih dari 100\%. Hasil diatas dapat disimpulkan bahwa kinerja Pemerintah Daerah Kota Batu ditinjau dari konsep value for money sudah baik karena telah memenuhi ekonomis, efisiensi dan efektifitas.

Khikmah, Alayyal (2014) meneliti tentang "Pengukuran Kinerja Pemerintah Daerah Kabupaten Lamongan Berdasarkan Konsep Value For Money". Hasil penelitian dalam pengukuran kinerja Pemerintah Daerah Kabupaten Lamongan berdasarkan konsep value for money diperoleh bahwa rasio ekonomis dari tahun 2009-2013 cenderung tidak ekonomis karena menghasilkan rasio lebih dari $100 \%$. Apabila dilihat dari segi efisiensinya, maka kinerja Pemerintah Daerah Kabupaten Lamongan cukup efisien karena rasio memperlihatkan hasil kurang dari $100 \%$. Artinya, pemerintah mampu mengelola keuangan daerah dengan menggunakan sumber daya dengan tingkat tertentu untuk dapat mencapai output yang optimum. Dan kinerja Pemerintah Daerah Kabupaten Lamongan efektif jika dilihat dari rasio efektivitas 
yang dihasilkan dari tahun 2009-2013. Di mana selama periode 5 tahun tersebut, perhitungan rasio menunjukkan hasil lebih dari $100 \%$, yang artinya bahwa pemerintah dalam menentukan target penerimaan telah sukses, dibuktikan dengan pemerolehan realisasi pendapatan yang lebih besar daripada anggaran pendapatannya.

Sari, Nindy Cahya Feriska (2014) meneliti tentang "Analisis Pengukuran Kinerja Pemerintah Daerah Dengan Menggunakan Prinsip Value For Money (Study Kasus Kabupaten Sumenep Tahun 2010-2013)". Hasil penelitian menunjukkan bahwa perhitungan rasio ekonomis menunjukkan kinerja pemerintah daerah berada pada katagori ekonomis, yaitu sebesar 88, $2 \%, 89,98 \%, 89,77 \%$ dan 90,68\%. Rasio efisiensi pada Kabupaten Sumenep periode 2010-2013 selalu mengalami peningkatan yaitu $99,44 \%, 96,55 \%, 95,36 \%, 92,91 \%$ dan berada pada kategori efisien. Sedangkan rasio efektifitas kinerja pemerintah Kabupaten Sumenep pada tahun 2010 tidak efektif hanya sebesar 99,95\% dan kurang dari 100\%, namun pada tahun 2011 hingga 2013 rasio efektifitas mengalami peningkatan sebesar 100,84\%, 101,21 \% dan 101, $28 \%$ dan berada pada kategori efektif, artinya pemerintah daerah dapat memperbaiki kinerja pemerintahannya secara efektif.

\section{METODE PENELITIAN}

\section{Objek dan Lokasi Penelitian}

Objek penelitian yang penulis teliti adalah Dinas Pengelolaan Keuangan dan Aset Daerah (DPKAD) Kota Lhokseumawe yang berlokasi di Jl. Merdeka - Kutablang No.145, Kuta Blang, Banda Sakti, Kota Lhokseumawe.

\section{Jenis dan Sumber Data}

Penelitian ini hanya menggunakan sumber data sekunder. Data sekunder pada umumnya berupa bukti, catatan atau laporan historis yang telah tersusun dalam arsip yang dipublikasikan dan tidak dipublikasikan.

Dalam penelitian ini data sekunder yang digunakan berasal dari DPKAD Kota Lhokseumawe yang berupa Laporan Realisasi Anggaran Pendapatan dan Belanja Daerah periode 2014-2016.

\section{Metode Pengumpulan Data}

\section{Dokumentasi dan Studi Pustaka}

Metode dokumentasi dilakukan dengan mengumpulkan data keuangan (anggaran dan realisasi anggaran), dokumen yang digunakan dalam penelitian ini adalah Laporan Anggaran Pendapatan dan Belanja Daerah (APBD) dan Laporan Realisasi Anggaran Pendapatan dan Belanja Daerah (RAPBD) Pemerintah Kota Lhokseumawe pada tahun 2014-2016. Metode studi pustaka dilakukan dengan mengumpulkan data berdasarkan sumber-sumber yang diperoleh dari literature yang membahas tentang konsep value for money.

\section{Definisi Operasional Variabel}

Variabel dalam penelitian ini adalah value for money. Value for money merupakan konsep pengukuran kinerja organisasi sektor publik yang berdasarkan pada tiga elemen yaitu ekonomi, efisiensi, dan efektivitas (Agustin, 2017).

a) Rasio Ekonomi

Konsep ekonomi sangat terkait dengan konsep biaya. Ekonomi memiliki pengertian bahwa sumber daya input hendaknya di peroleh dengan harga lebih rendah yaitu harga yang mendekati harga pasar. Nilai ekonomi dapat diukur dengan membandingkan antara input dan harga input. Dimana input merupakan sumber daya yang digunakan untuk pelaksanaan suatu kebijakan, program, dan kegiatan.

$$
\begin{aligned}
& \text { Rasio Ekonomis } \\
& =\frac{\text { Realisasi Pengeluaran }}{\text { Anggaran Pengeluaran }} \quad \text { x 100\% }
\end{aligned}
$$

Ketentuan:

Jika $<100 \%$ berarti ekonomis

Jika $>100 \%$ berarti tidak ekonomis

Jika $=100 \%$ berarti ekonomis berimbang

(Sumber: Khikmah, 2014)

Mahsun (2006:179) rasio ekonomi adalah mengukur tingkat kehematan dari pengeluaranpengeluaran yang dilakukan organisasi sektor publik, dimana pengukuran tersebut memerlukan data anggaran dan realisasinya.

b) Rasio Efisiensi

Efisiensi dapat diukur dengan pencapaian output yang maksimum dengan input tertentu atau penggunaan input terendah untuk mencapai output tertentu. Dimana output merupakan hasil yang dicapai dari suatu program, aktivitas, dan kebijakan, sedangkan input merupakan sumber daya yang digunakan untuk pelaksanaan suatu kebijakan, program, dan kegiatan.

$$
\begin{aligned}
& \text { Rasio Efisiensi } \\
& =\frac{\text { Realisasi Belanja }}{\text { Realisasi Pendapatan }} \text { x } \quad 100 \%
\end{aligned}
$$

Ketentuan:

Jika $<100 \%$ berarti efisien

Jika $>100 \%$ berarti tidak efisien

Jika $=100 \%$ berarti efisien berimbang

(Sumber: Khikmah, 2014)

Rasio efisiensi adalah rasio yang menggambarkan perbandingan antara besarnya 
realisasi biaya yang dikeluarkan terhadap realisasi pendapatan. Sehingga apabila sasaran yang ingin dicapai oleh suatu kebijakan publik ternyata terlalu sederhana sedangkan biaya yang dikeluarkan sangat besar dibandingkan dengan hasil yang dicapai, maka kebijakan tersebut tidak layak untuk dilaksanakan. Kinerja pemerintah dikatakan efisien apabila rasio yang dicapai kurang dari $100 \%$ atau semakin kecil rasio yang diperoleh, maka kinerjanya semakin efisien.

\section{c) Rasio Efektifitas}

Efektivitas dapat diukur dengan membandingkan antara outcome dengan output. Dimana outcome merupakan dampak yang ditimbulkan dari suatu aktivitas tertentu, sedangkan output merupakan hasil yang dicapai dari suatu program, aktivitas, dan kebijakan. Sehingga ukuran efektivitas dapat diartikan sebagai suatu standar akan terpenuhinya sasaran dan tujuan yang akan dicapai.

$$
\begin{aligned}
& \text { Rasio Efektifitas } \\
& =\frac{\text { Realisasi Pendapatan }}{\text { Anggaran Pendapatan }} \text { x 100\% }
\end{aligned}
$$

\section{Ketentuan:}

Jika $>100 \%$ berarti efektif

Jika $<100 \%$ berarti tidak efektif

Jika $=100 \%$ berarti efektif berimbang

(Sumber: Khikmah, 2014)

Halim (2008:234) rasio efektivitas adalah menggambarkan kemampuan pemerintah daerah dalam merealisasikan pendapatan yang direncanakan dibandingkan dengan anggaran yang ditetapkan.

\section{Metode Analisis Data}

Metode analisis data yang digunakan dalam penelitian ini adalah metode analisis deskriptif kualitatif. Metode analisis deskriptif kualitatif yaitu data hasil penelitian lebih berkenaan dengan interprestasi terhadap data yang ditemukan di lapangan yang kemudian diklasifikasikan dan dianalisis (Sugiyono, 2011:7).

\section{HASIL DAN PEMBAHASAN}

\section{Rasio Ekonomis}

Ekonomi adalah praktik pembelian barang dan jasa input dengan kualitas tertentu pada harga terbaik yang di mungkinkan (spending less). Pengertian ekonomi (hemat/tepat guna) sering disebut kehematan yang mencakup juga pengelolaan secara hati-hati atau cermat (prudency) dan tidak ada pemborosan.

Ekonomis (kehematan) sebagai tingkat biaya yang dikeluarkan untuk melaksanakan suatu kegiatan atau memperoleh sesuatu. Tingkat ekonomis sebuah anggaran bisa dilihat dari berapa presentase tingkat pencapaian. Tingkat ekonomi dalam mengelola keuangan dengan melihat perbandingan antara anggaran belanja dengan realisasinya dengan presentase tingkat pencapaiannya (Andriani, 2012). Rasio ekonomis atau perubahan biaya dikatakan baik apabila besarnya tingkat pembelanjaan yang direalisasikan lebih rendah dari yang sudah dianggarkan.

Tabel 2

Rasio Ekonomis Pemerintah Kota Lhokseumawe Tahun 2014-2016 (Dalam Rupiah)

\begin{tabular}{|l|l|l|l|}
\hline Tahun & $\begin{array}{l}\text { Realisasi } \\
\text { Pengeluaran }\end{array}$ & $\begin{array}{l}\text { Anggaran } \\
\text { Pengeluaran }\end{array}$ & Rasio Ekonomis \\
\hline 2014 & $727.480 .904 .420,00$ & $840.599 .869 .766,84$ & $86,54 \%$ \\
\hline 2015 & $879.070 .194 .380,00$ & $1.063 .632 .768 .408,58$ & $82,64 \%$ \\
\hline 2016 & $890.338 .348 .966,21$ & $1.246 .375 .866 .172,00$ & $71,43 \%$ \\
\hline
\end{tabular}

Sumber: Data Sekunder Diolah, 2018

Rasio ekonomis yang dihasilkan oleh pemerintah kotan lhokseunawe pada tahun tersebut dinilai ekonomis. Dikarenakan hasil rasio selama 3 tahun tersebut berada di bawah $100 \%$.

Dapat diketahui bahwa semakin rendah rasio ekonomi yang diperoleh maka semakin baik kinerja organisasi tersebut. Hal ini terbukti dengan adanya penghematan pada belanja operasi dan belanja modal seperti belanja barang, belanja peralatan dan mesin yang jauh lebih kecil dibandingkan dengan anggaran yang telah ditetapkan. Sehingga untuk indikator rasio ekonomis Pemerintah Kota Lhokseumawe sudah mencapai kinerja yang baik, karena dari tahun 2014-2016 (periode pengamatan), telah berhasil mengelola penggunaan anggaran belanja dengan baik.

\section{Rasio Efisiensi}

Pengertian efisiensi berhubungan erat dengan konsep produktivitas. Pengukuran efisiensi dilakukan dengan menggunakan perbandingan antara output yang dihasilkan terhadap input yang digunakan (cost of output). Proses kegiatan operasional dapat dikatakan efisien apabila suatu produk atau hasil kerja tertentu dapat dicapai dengan penggunaan sumber daya dan dana yang 
serendah-rendahnya (spending well). Pengukuran organisasi sektor publik dikatakan efisien apabila menghasilkan output sebesar-besarnya dan menggunakan input serendah-rendahnya.

Efisiensi (daya guna) berhubungan dengan metode operasi (method operation). Proses kegiatan operasional dapat dikatakan efisien apabila suatu produk atau hasil karya tertentu mempergunakan sumber daya dan dana yang serendah rendahnya. Efisiensi merupakan perbandingan antara output dan input. Kinerja Pemerintah Daerah dikatakan efisien apabila rasio yang dicapai kurang dari $100 \%$, atau Semakin kecil rasio efesiensi yang dicapai, maka kinerjanya semakin baik. Tingkat efisiensi dalam mengelola keuangan dengan melihat perbandingan antara realisasi anggaran belanja dengan realisasi anggaran pendapatan (Andriani, 2012).

Tabel 3

Rasio Efisiensi Pemerintah Kota Lhokseumawe Tahun 2014-2016 (Dalam Rupiah)

\begin{tabular}{|c|c|c|c|}
\hline Tahun & $\begin{array}{c}\text { Realisasi Biaya } \\
\text { untuk memperoleh } \\
\text { pendapatan }\end{array}$ & $\begin{array}{c}\text { Realisasi } \\
\text { Pendapatan }\end{array}$ & Rasio Efisiensi \\
\hline 2014 & $727.480 .904 .420,00$ & $768.270 .271 .382,74$ & $94,69 \%$ \\
\hline 2015 & $879.070 .194 .380,00$ & $835.809 .796 .431,35$ & $105,17 \%$ \\
\hline 2016 & $890.338 .348 .966,21$ & $908.888 .389 .623,51$ & $97,95 \%$ \\
\hline
\end{tabular}

Sumber: Data Sekunder Diolah, 2018

Pada tahun 2014 rasio efisiensi sebesar $94,69 \%$, kemudian mengalami peningkatan pada tahun 2015 yaitu sebesar 105,17\%, dan mengalami penurunan kembali pada tahun 2016 sebesar 97,95\%. Yang berarti bahwa kinerja Pemerintah Kota Lhokseumawe pada tahun 2014 dinyatakan efisien. Sedangkan pada tahun 2015 rasio efisiensi berada $>100 \%$ yang artinya pada tahun 2015 belanja Pemerintah Kota Lhokseumawe lebih besar dibandingkan pendapatannya. Hal ini menunjukkan bahwa kinerja pada tahun 2015 tidak efisien karena rasio yang melebihi $100 \%$. Kemudian tahun 2016, hal ini sama seperti pada tahun 2014 bahwa pada tahun 2016 rasionya kembali turun yang berarti efisien.

Namun secara keseluruhan kinerja Pemerintah Kota Lhokseumawe telah efisien, yang berarti bahwa Pemerintah Kota Lhokseumawe mampu menggunakan sumber daya yang diperlukan dengan minimum untuk mencapai target yang maksimum.

\section{Rasio Efektivitas}

Efektivitas adalah ukuran berhasil tidaknya suatu organisasi mencapai tujuannya. Efektifitas (hasil guna) adalah ukuruan keberhasilan suatu organisasi dalam usaha mencapai tujuan organisasi yang telah ditetapkan, efektifitas merupakan perbandingan outcome dan output. Outcome merupakan dampak suatu program atau kegiatan terhadap masyarakat sedangkan output merupakan hasil yang dicapai dari suatu program aktivitas dan kebijakan, tingkat efektifitas dalam pengelolaan keuangan dapat dilihat perbandingan realisasi angaran dengan anggaran pendapatan (penerimaan) dan presentase tingkat pencapaiannya (Putra, 2014).

Tabel 4

Rasio Efektifitas Pemerintah Kota Lhokseumawe Tahun 2014-2016 (Dalam Rupiah)

\begin{tabular}{|l|l|l|l|}
\hline Tahun & $\begin{array}{l}\text { Realisasi } \\
\text { Anggaran }\end{array}$ & Anggaran Pendapatan & Rasio Efektifitas \\
\hline 2014 & $768.270 .271 .382,74$ & $795.850 .276 .317,00$ & $96,53 \%$ \\
\hline 2015 & $835.809 .796431,35$ & $964.491 .807 .996,00$ & $86,65 \%$ \\
\hline 2016 & $908.888 .389 .623,51$ & $1.180 .645 .303 .809,00$ & $76,98 \%$ \\
\hline
\end{tabular}

Sumber: Data Sekunder Diolah, 2018

Dapat di ketahui bahwa pada tahun pengamatan mulai 2014-2016 dengan nilai rasio $96,53 \%, 86,65 \%, 76,98 \%$ rasio efektifitas yang bernilai $<100 \%$ menunjukkan bahwa kinerja pemerintah Kota Lhokseumawe pada tahun tersebut dinilai tidak efektif. Dikarenakan suatu organisasi sektor publik akan di katakan efektif apabila persentase rasionya $>100 \%$. Semakin besar rasio efektifitas yang didapat sebuah organisasi tersebut, maka semakin baik kinerja organisasi tersebut. Menurut Mardiasmo (134: 2004) menyatakan bahwa biaya boleh jadi melebihi apa 
yang telah dianggarkan, boleh jadi dua kali lebih lebih besar atau bahkan tiga kali lebih besar dari pada yang telah dianggarkan. Efektivitas hanya melihat apakah suatu program atau kegiatan telah mencapai tujuan yang telah ditetapkan.

Penelitian yang memperoleh rasio efektifitas dengan hasil yang efektif ialah yang mendapatkan persentase rasio di atas $100 \%$ atau lebih. Sebaliknya jika rasio yang diperoleh di bawah $100 \%$ maka hasil rasio ini bernilai tidak efektif. Ketidakefektifitas ini terjadi karena tidak mampunya Pemerintah Daerah dalam menyelesaikan target kegiatan atau program kerja yang telah ditetapkan. Sehingga terjadinya beberapa proyek fisik yang tidak dapat direalisasikan pada periode yang telah ditetapkan.

Hal ini terbukti dengan masih adanya kekurangan pada Pemerintah Kota Lhokseumawe, seperti banyaknya proyek fisik dan bantuan untuk masyarakat yang tidak dapat direalisasikan dengan Anggaran Pendapatan dan Belanja Kota (APBK) perubahan tahun 2016, bahkan terutang pada pihak ketiga (Sumber: Serambi Indonesia, 11 Desember 2016, akses: 9 Oktober 2017). Hutang tersebut diperkirakan berjumlah Rp 250.000.000.000 yang berasal dari kekurangan bayar dana pembangunan sejumlah proyek tahun lalu (2016) (Sumber: Kompas.com, 11 Maret 2017, akses: 18 Januari 2019).

\section{KESIMPULAN DAN SARAN}

\section{Kesimpulan}

Berdasarkan uraian yang telah dijelaskan pada bab-bab sebelumnya tentang penerapan konsep value for money pada Pemerintah Kota Lhokseumawe, maka dapat disimpulkan bahwa:

Dinas Pengelolaan Keuangan dan Aset Daerah (DPKAD) Kota Lhokseumawe dapat menerapkan value for money sebagai konsep pengukuran kinerjanya, karena dengan konsep value for money pemerintah dapat mengukur kinerja organisasi dengan lebih komprehensif, sehingga pemerintah dapat meningkatkan kinerjanya dimasa yang akan datang. Penerapan konsep value for money melalui tiga elemen, yaitu :

1. Rasio ekonomis pada Dinas Pengelolaan Keuangan dan Aset Daerah (DPKAD) Kota Lhokseumawe menunjukkan kinerja pemerintah daerah pada tahun 2014-2016 bernilai $86,54 \%, \quad 82,64 \%, \quad 71,43 \%$, menunjukkan bahwa rasio ini bernilai ekonomis. Sehingga untuk indikator rasio ekonomis Pemerintah Kota Lhokseumawe sudah mencapai kinerja yang baik, karena dari tahun 2014-2016 (periode pengamatan), telah berhasil mengelola penggunaan anggaran belanja dengan baik.

2. Rasio efisiensi kinerja Pemerintah Kota Lhokseumawe cukup baik. Dimana pada tahun
2014 nilai rasio efisiensi yang di peroleh senilai 94,69\% dan pada tahun 2015 naik menjadi $105,17 \%$ dan turun menjadi $97,95 \%$ pada tahun 2016, meskipun pada tahun 2015 menunjukkan rasio yang kurang efisien. Namun secara keseluruhan kinerja Pemerintah Kota Lhokseumawe telah efisien, yang berarti bahwa pemerintah mampu menggunakan sumber daya yang diperlukan dengan minimum untuk mencapai target yang maksimum. Karena, suatu organisasi akan di katakan efisien apabila rasio yang dicapai kurang dari $100 \%$ atau semakin kecil rasio yang diperoleh, maka kinerjanya semakin efisien.

3. Rasio efektifitas pada Pemerintah Kota Lhokseumawe periode 2014-2016 dengan nilai rasio $96,53 \%, 86,65 \%, 76,98 \%$ rasio efektifitas yang bernilai $<100 \%$ menunjukkan bahwa kinerja pemerintah Kota Lhokseumawe pada tahun tersebut dinilai tidak efektif.

\section{Saran}

Berdasarkan permasalahan yang ada dan dengan memperhatikan hasil dari analisis terhadap rasio kinerja Pemerintah Kota Lhokseumawe serta kesimpulan di atas, maka saran-saran yang mungkin berguna bagi peningkatan kinerja Pemerintah Kota Lhokseumawe dalam pengelolaan keuangan daerah antara lain sebagai berikut:

1. Pemerintah Kota Lhokseumawe dapat menerapkan konsep value for money sebagai salah satu metode yang dapat digunakan untuk menilai suatu perencanaan yang dibuat oleh Pemerintah Kota Lhokseumawe terhadap realisasinya.

2. Hasil perhitungan rasio ekonomis yang diterima oleh Pemerintah Kota Lhokseumawe baik, akan tetapi Pemerintah Kota Lhokseumawe harus dapat mengendalikan biaya-biaya/belanja yang dikeluarkan yang seharusnya disesuaikan dengan nominal yang telah dianggarkan, agar tidak menimbulkan pengeluaran yang boros dan tidak produktif, terutama pengeluaran-pengeluaran yang tidak bermanfaat bagi kepentingan public agar rasio ini dapat tetap bertahan atau bahkan bisa lebih meningkat lagi.

3. Hasil perhitungan rasio efisiensi dan rasio efektifitas yang kurang baik, Pemerintah Kota Lhokseumawe perlu meninjau penentuan target-target selanjutnya/yang akan datang, dan dapat menyusun strategi yang tepat agar tercapai tujuan pembangunan dan pengembangan daerah Kota Lhokseumawe. agar Kota Lhokseumawe dapat memperoleh rasio yang lebih baik dari sebelumnya dan terciptanya good govermant dan sukses dalam membangun daerahnya. 


\section{DAFTAR PUSTAKA}

Agustin, Risa Dwi. (2017). Konsep Value For Money Dalam Mengukur Kinerja Pelayanan Sektor Publik. Jurnal Ilmu dan Riset Akuntansi Sekolah Tinggi Ilmu Ekonomi Indonesia (STIESIA) Surabaya.

Andriani, Sri. (2012). Pengukuran Kinerja Dengan Prinsip Value For Money Pemerintah Kota Batu. Jurnal Fakultas Ekonomi, Universitas Islam Negeri Maulana Malik Ibrahim Malang.

Arfan, Demi Aulia. (2014). Analisis Value For Money Dalam Pengukuran Kinerja Dinas Pertanian Daerah Istimewa Yogyakarta Periode Tahun 2011-2012. Jurnal Fakultas Ekonomi Universitas Negeri Yogyakarta.

Bastian, Indra. 2006. Akuntansi Sektor Publik: Suatu Pengantar. Jakarta: Erlangga.

Ferina, Ika Sasti, dan Fika Arista. 2013. Penilaian Kinerja Dengan Menerapkan Indikator Value For Money Pada Kantor Pertanahan Kabupaten Musi Banyuasin Tahun 2009-2011. Jurnal Fakultas Ekonomi Akuntansi Universitas Sriwijaya.

Halim, Abdul. 2008. Akuntansi Sektor Publik. Jakarta: Salemba Empat.

Hasan, M. Iqbal. 2002. Pokok-pokok Materi Metodologi Penelitian dan Aplikasinya. Bogor: Ghalia Indonesia.

Hidayat, Taufik Wahyu. (2015). Pengukuran Kinerja Unit Kerja Pemerintah Daerah Dalam Perspektif Value For Money. Jurnal Ilmu \& Riset Akuntansi Sekolah Tinggi Ilmu Ekonomi Indonesia (STIESIA) Surabaya.

Khikmah, Alayyal. (2014). Pengukuran Kinerja Pemerintah Daerah Kabupaten Lamongan Berdasarkan Konsep Value For Money. Jurnal Fakultas Ekonomi Universitas Negeri Surabaya.

Kristanti, Okky Irvina. (2016). Analisis Kinerja Keuangan Melalui Pendekatan Value For Money (Studi Kasus di Unit Pelaksana Teknis Dinas Pendidikan Pemuda dan Olahraga Kecamatan Karimunjawa). Jurnal Jurusan Akuntansi Fakultas Ekonomi Universitas Sanata Dharma.
Kurniawati, Nova, dan Vidya Vitta Adhivinna. (2014). Analisis Penerapan Konsep Value For Money Pada Pemerintah Kabupaten Bantul. Jurnal Universitas PGRI Yogyakarta.

Liando, Harry Saputra, dkk. (2014). Analisis Kinerja Keuangan Pemerintah Kabupaten Kepulauan Sangie menggunakan metode Value For Money. Jurnal Fakultas Ekonomi dan Bisnis Jurusan Akuntansi Universitas Samratulangi Manado.

Mahmudi. 2005. Manajemen Kinerja Sektor Publik. Yogyakarta: UPP AMP YKPN

Mahsun, Mohamad. 2006. Pengukuran Kinerja Sektor Publik. Edisi Pertama. Yogyakarta: BPFE.

Mardiasmo. 2004. Akuntansi Sektor Publik. Yogyakarta: ANDI.

Nada, Syaza Lifia, dan Ikhsan Budi Riharjo. (2016). Pengukuran Kinerja Unit Kerja Pemerintah Daerah Dalam Perspektif Value For Money. Jurnal Ilmu dan Riset Akuntansi Sekolah Tinggi Ilmu Ekonomi Indonesia (STIESIA) Surabaya.

Nordiawan, Deddi, dan Ayuningtyas Hertianti. 2010. Akuntansi Sektor Publik, Edisi 2. Jakarta: Salemba Empat.

Nugrahani, Tri Siwi. (2007). Analisis Penerapan Konsep Value For Money Pada Pemerintah Daerah Istimewa Yogyakarta. Jurnal AKMENIKA UPY.

Putra, Renaldi. (2014). Penerapan Konsep Value For Money Dalam Menilai Kinerja Pelayanan Sektor Publik Pada Polres Ogan Ilir. Fakultas Ekonomi Universitas Bina Darma.

Sari, Nindy Cahya Feriska. (2014). Analisis Pengukuran Kinerja Pemerintah Daerah Dengan Menggunakan Prinsip Value For Money (Study Kasus Kabupaten Sumenep Tahun 2010-2013). Jurnal Fakultas Ekonomi Universitas Negeri Surabaya.

Setiyawati, Yuly Indah. (2015). Pengukuran Kinerja Unit Kerja Pemerintah Daerah Dengan Perspektif Value For Money. Jurnal Ilmu \& Riset Akuntansi Sekolah Tinggi Ilmu Ekonomi Indonesia (STIESIA) Surabaya. 
Keuangan

Subastian, Avib. 2013. Laporan Akuntabilitas Kinerja Dinas Pendidikan Kota Surabaya Melalui Pendekatan Value For Money. Jurnal Ilmu \& Riset Akuntansi Sekolah Tinggi Ilmu Ekonomi Indonesia (STIESIA) Surabaya.

Sugiyono. 2013. Metode Penelitian Pendidikan (Pendekatan Kuantitatif, Kualitatif, dan $R \& D)$. Bandung: Alfabeta.

Suwandi, Mega Maranda. (2017). Pengukuran Kinerja Instansi Pemerintah Dalam Perspektif Value For Money. Jurnal Ilmu \& Riset Akuntansi Sekolah Tinggi Ilmu Ekonomi Indonesia (STIESIA) Surabaya.

Ulum MD, Ihyaul. 2012. Audit Sektor Publik. Jakarta: Bumi Aksara.

Sumber Internet:

http://aceh.tribunnews.com/2016/12/11/kas-pemkokosong akses: 9 Oktober 2017.

https://properti.kompas.com/read/2017/03/11/2037 26021/danai.pembangunan.pemkot.lhokse umawe.utang.rp.250.miliar akses: 9 Oktober 2017 